Descartes's Dualism 



\section{Descartes's Dualism}

$\sim M A R L E E N$ ROZEMOND

HARVARD UNIVERSITY PRESS

Cambridge, Massachusetts, and London, England 
Copyright (C) 1998 by the President and Fellows of Harvard College All rights reserved

Printed in the United States of America

This book has been digitally reprinted. The content remains identical to that of previous printings.

Library of Congress Cataloging-in-Publication Data

Rozemond, Marleen.

Descartes's dualism / Marleen Rozemond.

p. $\mathrm{cm}$.

Includes bibliographical references and index.

ISBN 0-674-19840-9

1. Descartes, René, 1596-1650-Contributions in dualist doctrine of mind and body. 2. Mind and body-History-17th century. I. Title.

B1878.M55R68 1998

$128^{\prime} .2-\mathrm{dc} 21 \quad 97-42399$ 
For Sam 
